\title{
POSITIVE AND NEGATIVE ASPECTS OF SULPHATE-REDUCING BACTERIA IN ENVIRONMENT AND INDUSTRY
}

\author{
ALENA LUPTAKOVA ${ }^{1}$, EVA MACINGOVA ${ }^{1}$, \\ VLASTA HARBULAKOVA ${ }^{2}$ \\ ${ }^{1}$ Department of Mineral biotechnology, Institute of Geotechnics of Slovak Academy of \\ Sciences, Watsonova 45, Kosice, SK-043 53, Slovak Republic \\ (luptakal@saske.sk),(macingova@saske.sk) \\ ${ }^{2}$ Technical University of Košice, Civil Engineering Faculty, Institute of Building and \\ Environmental Engineering, Vysokoškolská 4, Košice, SK-042 00, Slovak Republic,
}

(vlasta.harbulakova@tuke.sk)

\begin{abstract}
The submitted work is oriented on the study of two aspects of the sulphate-reducing bacteria metabolism: the metals bioprecipitation and the concrete biodeterioration.

The bioprecipitation of metals with the bacterially produced hydrogen sulphide by sulphate-reducing bacteria (SRB) represents the positive effect of the SRB existence in the environment. It allows the industrial exploitation in the area of the removal metals from industrial wastewaters. Referred method involves principal stages such as: hydrogen sulphide bacterial production, metals precipitation by biologically produced hydrogen sulphide, metal sulphides separation, setting $\mathrm{pH}$ of the filtrate from previous steps by $1 \mathrm{M} \mathrm{NaOH}$ and metal hydroxides separation. The basis of the first stage i.e. the hydrogen sulphide bacterial production is the cultivation of SRB. In the laboratory conditions the sodium lactate is the energetic substrate for the growth of bacteria. Its price is not economic for the application in the practice and is needed investigate the alternative substitutes. Therefore was studied the cultivation of sulphate-reducing bacteria to using the selected energetic substrates such as: calcium lactate, glycerol and whey. Experimental studies confirm that all chosen substrates are suitable alternative substrates of sodium lactate for the bacterial sulphate-reduction. In the regard to the efficiency of bacterial sulphate reduction the calcium lactate is the best.

The biodeterioration of the concrete presents the negative effect of the SRB existence in the environment. The research was oriented on the simulation of the biodeterioration of concrete samples under the simultaneous influence of the sulphur-oxidising bacteria genera Acidithiobacillus thiooxidans and sulphatereducing bacteria genera Desulfovibrio in the environs of the waste water, the acid mine drainage, the nutrient medium and the distilled water. The observation of the surface structure changes of concrete samples confirms the highest biodeterioration influences in the case of the acid mine drainage application.
\end{abstract}

Key words: sulphate-reducing bacteria, sulphur-oxidising bacteria, sulphuretum, bioprecipitation, biodeterioration

\section{Introduction}

Sulphur is widely distributed on the earth and occurs predominantly bound in the form of sulphides, sulphates or as elemental sulphur. In the nature sulphur circulates permanently because it is continuously oxidized or reduced by chemical or biological processes. In a biogeochemical sulphur cycle (Fig. 1) the biological transformations may have either assimilatory or dissimilatory metabolic functions. With the exception of animals and humans, most plants, fungi and bacteria are capable of performing an assimilatory reduction of sulphate to sulphide, which is necessary for the biosynthesis 
of sulphur containing cell compounds. On the other hand the energy producing dissimilatory sulphur metabolism is restricted to a few groups of bacteria. These groups include microorganisms such as: anaerobic dissimilatory sulphate reducers (bacteria Desulfovibrio, Desulfotomaculum, Desulfomonas,....), anaerobic dissimilatory sulphur reducers (bacteria such as Desulfuromonas,...), anaerobic phototrophic sulphur oxidisers (some cyanobacteria and most anoxygenic phototrophic bacteria), aerobic chemotrophic sulphur oxidisers (bacteria such as Acidithiobacillus, Sulfolobus, Thiospira, Thiobacterium, ....), anaerobic chemotrophic sulphur oxidisers (bacteria such as Acidithiobacillus denitrificans, Thiomicrospira denitrificans,..) (REHM and REED, 1981).

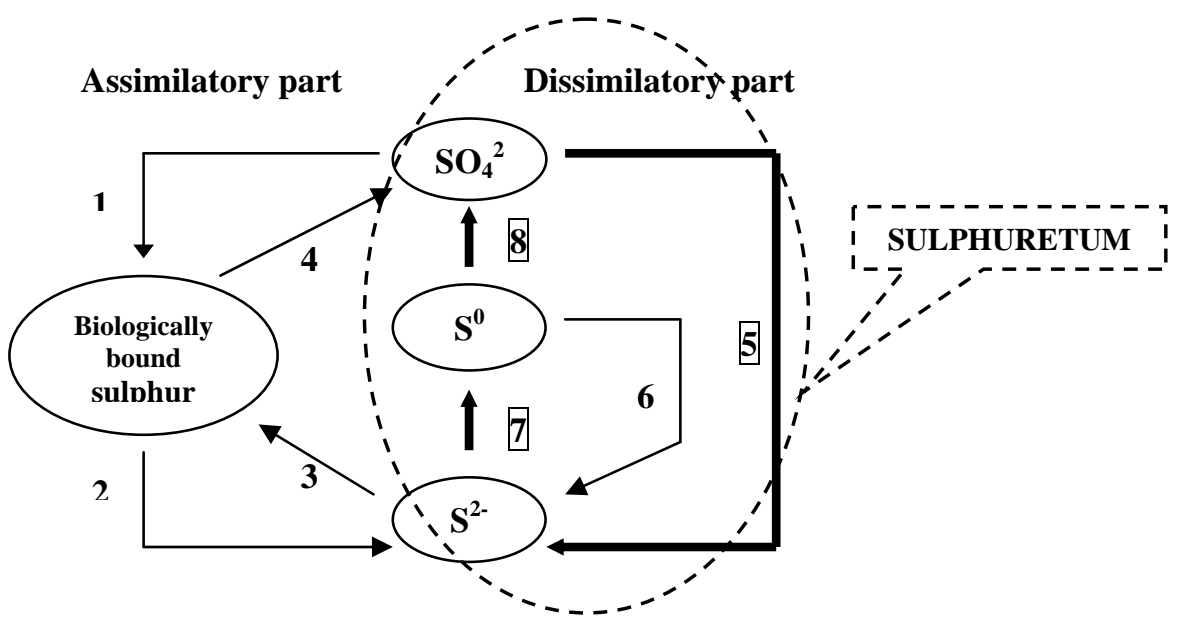

Fig. 1. The biological sulphur cycle (REHM and REED, 1981; conformed). 1 - assimilatory sulphate reduction by plants, fungi and bacteria; 2 - death and decomposition by fungi and bacteria; 3 - sulphide assimilation by bacteria and some plants; 4 - excretion of sulphate by animals; 5 - dissimilatory sulphatereducing bacteria; 6 - dissimilatory sulphur-reducing bacteria; 7 - phototrophic and chemotrophic sulphideoxdizing bacteria; 8 - phototrophic and chemotrophic sulphur-oxidizing bacteria.

The microbial population of dissimilatory part is called "sulphuretum". Its activity is the fundamental of many processes in the nature and industry (e.g. biocorrosion, bioleaching, bioprecipitation, biodeterioration).

The typical species of sulphate-reducing bacteria (SRB) is Desulfovibrio desulfuricans, which reduce sulphates according the reaction (1):

$$
2 \mathrm{CH}_{3} \mathrm{CHOHCOO}^{-}+\mathrm{SO}_{4}{ }^{2-} \stackrel{\mathrm{SRB}}{\longrightarrow} 2 \mathrm{CH}_{3} \mathrm{COO}^{-}+2 \mathrm{HCO}_{3}^{-}+\mathrm{H}_{2} \mathrm{~S}
$$

SRB produce considerable amount of hydrogen sulphide $\left(\mathrm{H}_{2} \mathrm{~S}\right)$. Consequently participation of biologically produced hydrogen sulphide in next processes mentions on the positive or negative influence of the SRB metabolism in the environment and industry (Table 1). 
Table 1. Some influence of the SRB metabolism in the environment and industry.

\begin{tabular}{|c|c|}
\hline Positive influence & Negative influence \\
\hline Attendance in biogenesis of oil hydrocarbons & Biocorrosion of pumping machinery \\
\hline Attendance in biogenesis of sulphur deposits & $\begin{array}{l}\text { Blackening and discoloration of } \\
\text { products }\end{array}$ \\
\hline Participation in the biological sulphur cycle & Biodeterioration of concrete \\
\hline Removal of heavy metals from waste waters & Biodeterioration of building materials \\
\hline Removal of $\mathrm{SO}_{4}{ }^{2-}$ from mine waters & Production of smell \\
\hline Production of sulphur from waste waters & Devaluation of gasoline \\
\hline Removal of sulphur from crude oil, petrol and coal & \\
\hline
\end{tabular}

\subsection{Positive influence of the SRB metabolism in the environment and industry}

The positive influence of SRB is based on the process called bioprecipitation, when the biologically produced hydrogen sulphide precipitates of heavy metals from aqueous solution in the metal sulphides form. Along this line the bacterial sulphate reduction (reaction 1) has the major application for the removal of heavy metals from industrial waste waters. It is suitable method for removal heavy metals from acid mine drainage (AMD). AMD generation is the most serious environmental problem created mainly by the mining industry of the sulphide minerals. The impacts of acid mine water pollution on biological systems are mostly severe. The consequence of acidity and heavy metal contamination of AMD in aquatic and terrestrial ecosystems is a reduction in both species diversity and the total biomass composition of systems. Nowadays is pay attention to biotreatment of AMD by selective sequential precipitation to recover metals as hydroxides and sulphides. It is the process of the heavy metals precipitation by bacterially produced hydrogen sulphide with the combination of the metals precipitation by sodium hydroxide at the various values of pH AMD (TABAK et al., 2003).

In general these methods involve principal stages such as: the biological sulphate reduction i.e. the hydrogen sulphide bacterial production, the metals precipitation by biologically produced hydrogen sulphide, the precipitate filtration, the setting $\mathrm{pH}$ of the filtrate by $1 \mathrm{M} \mathrm{NaOH}$ with simultaneously precipitation of metals as hydroxides and metal hydroxides separation. The basis of the first stage the biological sulphate reduction is the cultivation of SRB. In the laboratory conditions the sodium lactate is the energetic substrate for the growth of bacteria. Its price is not economic for the application in the practice and is needed investigate the alternative substitutes.

Various types of organic substances have been employed as electron donors and carbon sources including sewage sludge, wood chips, animal manure, vegetal compost, mushroom compost, whey and other agricultural waste (DVORAK et al., 1992). In addition, synthetic organic compounds have also been used as electron donors, especially small molecular weight compounds, such as lactate, acetate, propionate, pyruvate and butyrate. Ethanol and other alcohols can also be used. Nearly all of these compounds are known to be fermentation products of anaerobic bacterial 
degradation of carbohydrates, proteins and other constituents of dead biomass. Molasses, which contains a high amount of sucrose, has also been used as electron donor. Therefore was studied the cultivation of SRB to using the selected energetic substrates such as: calcium lactate, glycerol and whey.

\subsection{Negative influence of the SRB metabolism in the environment and industry}

On the negative influence of the SRB to suggest the aspect of the biologically produced hydrogen sulphide oxidation by bacteria Acidithiobacillus thiooxidans to the sulphuric acid, which corrode some materials. This process is named the concrete biocorrosion or the concrete biodeterioration. It is the term for the concrete destruction by biogenic acid (e.g. biogenic sulphuric acid) that is generated predominantly by the sulphur-oxidising bacteria genera Acidithiobacillus thiooxidans and sulphate-reducing bacteria genera Desulfovibrio through diverse mechanisms (OKABE et al., 2007). The concrete biodeterioration has a serious economic impact worldwide, especially when the replacement or repair of municipal sewer systems is required. In sewer systems and wastewater treatment facilities where high concentrations of hydrogen sulphide, moisture, and oxygen are present in the atmosphere, the deterioration of concrete is caused mainly by biogenic sulphuric acid. Roberts et al. described the general mechanism for the sulphuric acid caused corrosion of sewer systems (ROBERTSET et al., 2002). In the first step, hydrogen sulphide is produced by SRB under anaerobic conditions in sewer pipes. This one enters the sewer atmosphere by volatilization and dissolves in the condensate on the sewer crown. Finally, sulphur-oxidizing bacteria Acidithiobacillus thiooxidans oxidize the dissolved hydrogen sulphide and other sulphur compounds to sulphuric acid, which corrodes the concrete.

\section{Materials and methods}

\subsection{Positive influence of the SRB metabolism in the environment and industry}

Microorganisms - the cultures of SRB (Desulfovibrio desulphuricans) were used, which was isolated from the potable mineral water (Gajdovka spring, Slovakia). Bacteria Desulfovibrio desulphuricans were selected from the mixed cultures by the modified dilution method (KARAVAJKO et al., 1988).

Cultivation of sulphate-reducing bacteria - series of cultivation tests were studied in the hermetically closed glass jar at $30{ }^{\circ} \mathrm{C}$, during 10 days under anaerobic conditions. The anaerobiosis was generated by an inert gas $\left(\mathrm{N}_{2}\right)$ and chemically with sodium thioglycollate. The total volume of filling solution with $\mathrm{pH} 7.5$ consisted from $50 \mathrm{ml}$ of the bacterial cultures and $400 \mathrm{ml}$ the classical selective nutrient medium DSM-63 - Postgate's C (the energetic substrate for the growth of SRB was sodium lactate (DL -Na)) or its the modifications. The basis of this modification was the DL- 
Na substitution by the adequate amount of chosen substrates: the calcium lactate (DL$\mathrm{Ca}$ ), the glycerol (GLY) and the whey (SRV). Sodium lactate, calcium lactate and glycerol were used in the form of chemicals with the analytical grade. Whey was bought in the chemist (i.e. non analytical grade).

Analytical procedures - a turbidimetric method was used to measure the sulphate concentration. A glass $\mathrm{pH}$ electrode combined with the reference $\mathrm{Ag} / \mathrm{AgCl}$ electrode was used to measure pH by digital pH- meter GPRT 144 AGL (Germany).

\subsection{Negative influence of the SRB metabolism in the environment and industry}

Microorganisms - for the experiments were used two types of bacterial cultures: sulphate-reducing bacteria Desulfovibrio desulphuricans and sulphur-oxidising bacteria Acidithiobacillus thiooxidans. Bacteria Desulfovibrio desulphuricans were isolated from the potable mineral water (Gajdovka spring, Slovakia). The SRB were selected from the mixed cultures by the modified dilution method (KARAVAJKO et al., 1988). Bacteria Acidithiobacillus thiooxidans were isolated from the acid mine water (the shaft Pech, the deposit Smolník, Slovakia). The isolation and following cultivation of the Acidithiobacillus thiooxidans clean bacterial culture was realised using Waksman's and Joffe's selective nutrient medium by the plate dilution method (KARAVAJKO et al., 1988).

Concrete specimens - concrete samples in the cylinder form (25 mm diameter and $20 \mathrm{~mm}$ height) were taken from pipes produced using the normal industrial processes. Before experiments samples were sterilized in $70 \%$ ethanol and dried in oven at $60^{\circ} \mathrm{C}$ to constant weight.

Concrete biodeterioration - the glass desiccator was used as reactor. Concrete samples were put into reactor and inserted into four containers: the first was filled by waste water (WW), the second by acid mine drainage (AMD), the third by nutrient medium for Acidithiobacillus thiooxidans (NM) and the fourth by distillated water (DV). The reactor was interconnected with the flask filled by bacterial cultures Desulfovibrio desulphuricans and the flask filled by cadmium acetate for to capture of $\mathrm{H}_{2} \mathrm{~S}$. Concrete samples were every 7 days inoculated by Acidithiobacillus thiooxidans and in the same period the change of nutrient medium for Desulfovibrio desulphuricans were realized during 90 days.

Methods - the disruption and damages of the concrete surface were investigated by stereomicroscopy, atomic force microscopy (AFM) and electron microscopy. Mineralogical stereomicroscope STM 723 ZOOM with the combination of digital camera Olympus - C-770 Ultra Zoom was used for upper (not immersed) part concrete samples study because of noticeable changes in structure of concrete. AFM (JPK Instruments, Germany) was used for both (immersed and not immersed) parts of concrete samples investigation. A NanoWizardII contant mode AFM was used to image the surface of concrete samples. Compounds precipitated onto samples surface were investigated by scanning electron microscopy (SEM). The qualitative analyses of precipitates from samples surface were investigated by energy dispersive spectrometry (EDS) analysis. 


\section{Results and discussion}

\subsection{Positive influence of the SRB metabolism in the environment and industry}

The growth of SRB in all liquid mediums (without abiotic controls) was demonstrated by the sensorial detection of $\mathrm{H}_{2} \mathrm{~S}$ typical odour, the SRB presence by the origin of $\mathrm{FeS}$ according following reaction (2), $\mathrm{Fe}^{2+}$ is standard compound of nutrient medium DSM-63 - Postgate's C:

$\mathrm{Fe}^{2+}+\mathrm{H}_{2} \mathrm{~S} \longrightarrow \mathrm{FeS}+2 \mathrm{H}^{+}$

During experiments were observed the decrease of the sulphates concentration. The formation of black precipitates, the sensorial detection of classical strong $\mathrm{H}_{2} \mathrm{~S}$ smell and the decrease of sulphate concentration were not observed in the abiotic control. It confirms that aforesaid changes were caused by the bacterial metabolism of SRB. Fig. 2 documents, that all used substrates are suitable alternative substitutes. In the regard to the amount of reduced sulphates the calcium lactate is the best.

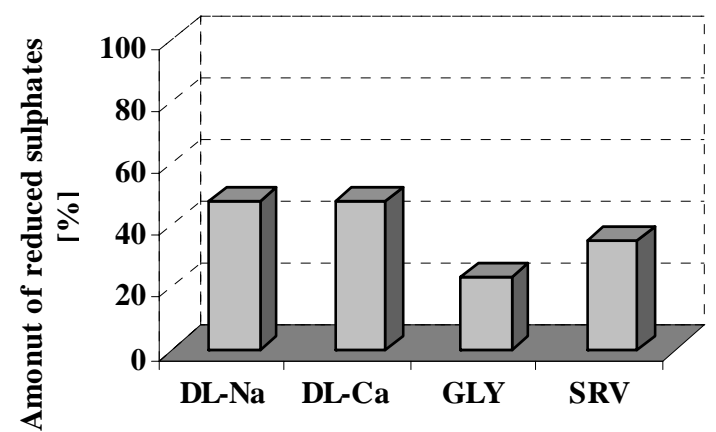

Fig. 2. Comparison of reduced sulphates amount with SRB by using substrates: sodium lactate (DL-Na), calcium lactate (DL-Ca), glycerol (GLY), whey (SRV).

\subsection{Negative influence of the SRB metabolism in the environment and industry}

The most considerable biodeterioration of concrete was observed on samples immerged into acid mine drainage. In the first instance the changes of concrete samples structures were observed by stereomicroscopy. Fig. 3 illustrates a surface of concrete specimen before experiment. Fig. 4 shows the visible surface changes after 90 days sulfuretum simulation of samples taken from AMD. For detailed study of concrete samples surface changes AFM method was used. In Fig. 5 the surface of concrete sample before experiment is shown. The surface is quite smooth, with the low roughness. Fig. 6 demonstrates the image of samples taken from AMD after 90 days sulfuretum simulation. On figure is visible that the roughness increased and some aggregates were fallen out of concrete surface. 


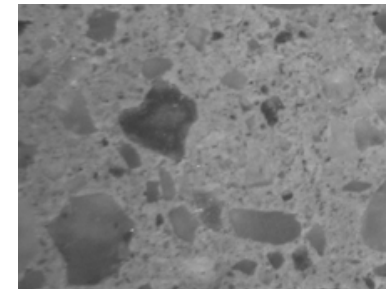

Fig. 3. Smooth surface filling among aggregates before experiment. Stereomicroscopy. Magnification of image 20 x 4.5

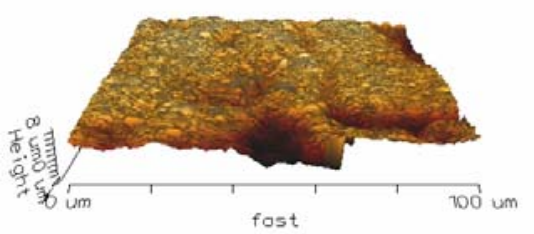

Fig. 5. Surface of concrete sample before experiment. Atomic force microscopy.

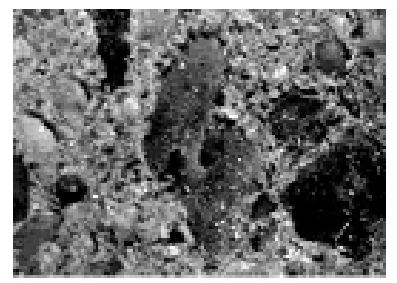

Fig. 4. Considerable biodeterioration of concrete sample surface after 90 days, samples taken from AMD. Stereomicroscopy. Magnification of image 20 x 4.5

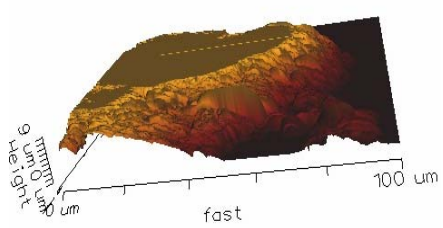

Fig. 6. AMD immersed part of concrete sample Atomic force microscopy.

During the experiment the pH values of leachate AMD were increasing up 7.03. Depends on $\mathrm{pH}$ the lath-shaped crystals of ettringit $\left(3 \mathrm{CaO} \cdot \mathrm{Al}_{2} \mathrm{O}_{3} \cdot 3 \mathrm{CaSO}_{4} \cdot 32 \mathrm{H}_{2} \mathrm{O}\right)$ were on the surface observed as shown on Fig. 7 and 8 . The ettringite is secondarily produced under alkaline conditions after exposure to sulphate (MORI et al., 1992).

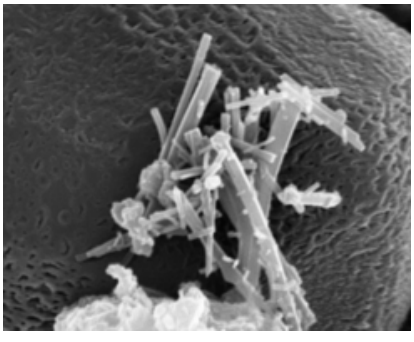

Fig. 7. Image of ettringit crystals precipitated on the concrete sample surface underwater into AMD (SEM).

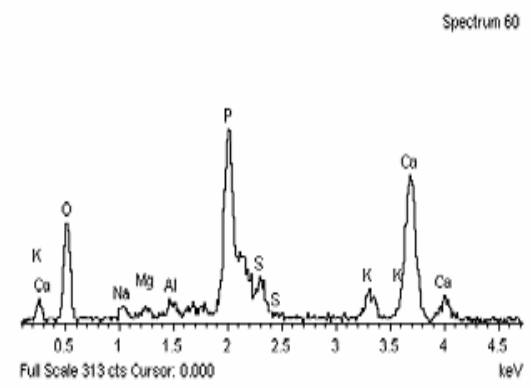

Fig. 8. EDS qualitative ettringite analysis.

\section{Conclusion}

Experimental studies of the part "Positive influence of the SRB metabolism in the environment and industry" confirm that all chosen substrates calcium lactate, glycerol and whey are suitable alternative substrates of sodium lactate for the bacterial 
sulphate-reduction. In the regard to the efficiency of bacterial sulphate reduction the calcium lactate is the best. Efficiency of bacterial sulphate reduction in the case of whey was less compared with calcium lactate. But in experiments was used reclaimed and dried whey. Consequently next experiments will orient on the application of whey from dairy works. It is the dayiring industry waste with low cost.

Experimental studies of the part "Negative influence of the SRB metabolism in the environment and industry" confirmed visible changes of concrete samples surface structure by the bacteria attack. Concrete samples were under biogenic sulphuric acid influence corroded. The most considerable biocorrosion was observed on samples immerged into acid mine drainage. Experiment simultaneous effect of bacteria Acidithiobacillus thiooxidans and Desulfovibrio desulphuricans, which were the source of $\mathrm{H}_{2} \mathrm{~S}$ has proven. Crystals participated on concrete surface was identified as ettringite.

Acknowledgment: This work was supported by the Slovak Research and Development Agency under the contract No. APVV-51-027705 and grant agency VEGA for project No. 2/0075/08. I also thank University of Duisburg-Essen, Biofilm Centre, Aquatic Biotechnology, Dusburg, Germany especially group of prof. Wolfgang Sand for opportunity to work with AFM.

\section{References}

DVORAK, D.H et al.: Treatment of metal-contaminated water using bacterial sulfate reduction: results from pilot-scale reactors. Biotechnol. Bioeng., 40, 1992, 609-16.

KARAVAJKO, G.I., ROSSI, G., AGATE, A.D., GROUDEV, S.N. and AVAKYAN, Z.A.: Biogeotechnology of metals. Centre of projects GKNT, Moscow, 1988, 350 pp.

MORI, T.: et al.: Interactions of nutrients, moisture and $\mathrm{pH}$ on microbial corrosion of concrete sewer pipes. Water Res., 26, 1992, 29-37.

OKABE, S., ODAGIRI, M., ITO, T., and SATOH, H.: Succession of Sulfur-Oxidizing Bacteria in the Microbial Community on Corroding Concrete in Sewer Systems. Appl. Environ. Microbiol., 73, 2007, 971-980.

REHM, H.J., REED, G.: Biotechnology, Vol. 6b, Verlag Chemie GmbH, Weuheim, 1981, 473-475.

ROBERTS, D. J., NICA, D., ZUO, G., and DAVIS, J.L.: Quantifying microbially induced deterioration of concrete: initial studies. Int. Biodeterior. Biodegrad., 49, 2002, 227-234.

TABAK, H.H., SCHARP, R., BURCKLE, J., KAWAHARAI, F.K., GOVIND, R., Advances in biotreatment of acid mine drainage and biorecovery of metals: 1 . Metal precipitation for recovery and recycle. Biodegradation, 14, 2003, 423-436. 